\title{
Quality of calcium and magnesium silicate coated Phaseolus vulgaris seeds
}

Patrícia Migliorini, Cristina Rossetti, Andreia da Silva Almeida, Nícolas de Conceição Ávila, Natalia Pedra Madruga, Filipe Pedra Mattos, Lilian Vanussa Madruga de Tunes

Universidade Federal de Pelotas - UFPEL, Departamento de Fitotecnia, RS. E-mail: cristinarosseti@yahoo.com.br

\section{Resumo}

Objetivou-se com este trabalho avaliar o efeito do revestimento de sementes de feijão com diferentes doses de silício (Si) em seus atributos físicos, fisiológicos e sanitários, bem como determinar a quantidade nutrientes absorvido nas plântulas. Utilizaram-se sementes de feijão BRS Expedito, safra 2014/15, com germinação inicial de $82 \%$. Sendo utilizado como fonte de $\mathrm{Si}$, pó de silicato de cálcio e magnésio (Agrosilício ${ }^{\circledR}$ ) (Si:10,53\%; Ca:25,00\%; Mg:7,00\%; Fe:10,20\%; Cr:4,48\%; Mn:1,72\%; Ti:0,69\%; S:0,52\%; $\mathrm{K}: 0,35 \%)$, previamente peneirado, apresentando uma densidade $1,30 \mathrm{~g} / \mathrm{cm}^{3}$. O tratamento constituiu no recobrimento de sementes de feijão, nas doses equivalentes de $0,45,90,135$ e $180 \mathrm{~g} \mathrm{Si} 100 \mathrm{~kg}^{-1}$ de sementes, o que correspondeu a $0 ; 427,3 ; 854,7 ; 1,282 ; 1,709 \mathrm{~g}$ do produto para $100 \mathrm{~kg}^{-}{ }^{1}$ de sementes. 0 aumento de doses de até $116 \mathrm{~g}$ de Si $100 \mathrm{~kg}^{-1}$ de sementes influência positivamente a expressão do vigor, propiciando um desenvolvimento superior das plântulas, bem como o aumento da concentração de Si nas folhas e no Ca da raiz. Doses diferentes de Si não controlam patógenos associados a sementes.

Palavras-chave: feijão, patógenos, qualidade física, qualidade fisiológica, silício.

\section{Qualidade de sementes de Phaseolus vulgaris revestidas com silicato de cálcio e magnésio}

\begin{abstract}
The objective of this work was to evaluate the effect of bean seed coating with different doses of silicon (Si) on their physical, physiological and sanitary attributes, as well as to determine the amount of nutrients absorbed in the seedlings. BRS Expedito beans, 2014/15 harvest, were used, with an initial germination of $82 \%$. Being used as a source of $\mathrm{Si}$, calcium and magnesium silicate powder (Agrosilício ${ }^{\circledR}$ ) (Si: 10.53\%; Ca: 25.00\%; Mg: 7.00\%; Fe: 10.20\%; Cr: 4 , 48\%; Mn: 1.72\%; Ti: 0.69\%; S: 0.52\%; K: 0.35\%), previously sieved, with a density of $1.30 \mathrm{~g} / \mathrm{cm}^{3}$. The treatment consisted of covering bean seeds, in the equivalent doses of 0 , $45,90,135$ and $180 \mathrm{~g}$ Si $100 \mathrm{~kg}-1$ of seeds, which corresponded to $0 ; 427.3 ; 854.7 ; 1,282 ; 1.709 \mathrm{~g}$ of the product for $100 \mathrm{~kg}-1$ of seeds. The increase in doses of up to $116 \mathrm{~g}$ of Si $100 \mathrm{~kg}-1$ of seeds positively influences the expression of vigor, providing a superior development of seedlings, as well as an increase in the concentration of $\mathrm{Si}$ in the leaves and root $\mathrm{Ca}$. Doses other than Si do not control pathogens associated with seeds.
\end{abstract}

Key words: beans, pathogens, physical quality, physiological quality, silicon.

\section{Introduction}

The use of seeds of high physical, physiological, genetic and health quality, allied to proper management practices with the use of mineral nutrients, can guarantee during the initial phase of the crop, an adequate stand and satisfactory vegetative development, which are requirements necessary to obtain good productivity levels in bean crop (MONDO et al., 2016). Seed germination is known to be one of the most important stages in plant development, during this period several factors can interfere with a rapid and uniform emergence. Seed coating with silicon (Si) may be an alternative to improve field seed and seedling performance when subjected to adverse environmental conditions (RUFINO et al., 2017).

Thus, the evaluation of the physiological and sanitary potential after seed treatment, allows to estimate the capacity of the seeds to 
adequately manifest their vital functions after sowing, ensuring that this management practice is safe in order to provide good results of seed development seedlings in the field (TUNES et al., 2015).

$\mathrm{Si}$ is considered a nonessential element for plants, according to the concept of nutrient essentiality, however its beneficial effects on crops have been widely reported. Especially when plants are subjected to biotic and abiotic stresses such as attack by pathogens and pests, water deficiency, salinity, heavy metals, high or low temperature, nutritional imbalance and among other factors (DEBONA et al., 2017).

$\mathrm{Si}$ accumulation in different species ranges from 1 to $100 \mathrm{~g} \mathrm{~kg}^{-1} \mathrm{Si}$ in shoot dry matter. The absorption of $\mathrm{Si}$ in non-accumulative plants such as beans will depend on the availability of the element in the medium, which will accumulate in different amounts in different parts of the plant (MITANI; MA, 2005; TUBANA et al., 2017).

The effects of this element are poorly understood, but it is known that its accumulation in tissues is necessary to enhance physiological responses (DALLAGNOL et al., 2009). In most dicotyledons the absorption occurs passively by mass flow, being absorbed as monosilicic acid $\left(\mathrm{H}_{4} \mathrm{SiO}_{4}\right)$ and distributed in the plant by the transpiration rate. Deposited on the outer walls of leaf epidermal cells as polymerized acid (amorphous silica), once deposited, Si does not redistribute to new organs, requiring new applications (CARNEIRO et al., 2010; HAYNES, 2017). The common bean is affected by innumerable pathogens, that in the great majority are transmitted by seeds and that can cause serious damages, as reduction of the germination, emergence and in the growth of the seedlings, leading to death in pre or post emergence, compromising the root system and the vascular which will prevent the transport of water and nutrients, in addition to spreading diseases in crops, resulting in losses in production (SILVA et al., 2008; MARCENARO; VALKONEN, 2016).

Thus, mineral nutrition through seed coating is a technology that can provide adequate conduction of agricultural crops, promoting adequate stands and strengthening seedling defenses against seed-borne pathogens or in the soil in the stages culture initials. Si sources are generally found in steel slag (silicate), originating from high temperature processing, from the reaction of limestone (calcite, magnesian or dolomitic), with silica $\left(\mathrm{SiO}_{2}\right)$ present in iron ore elements such as $\mathrm{Ca}$ and Mg (DEUS; BÜLL, 2013). Si can also be found in a by-product of the rice industry, obtained from rice husk extracted from the beneficiation and carbonized in special ovens at controlled temperature (CASTELLANOS et al., 2016). Both sources are rich in $\mathrm{Si}$ and economically reasonable, since they are obtained from industrial and regional waste. In this context, the objective of this study was to evaluate the effect of different doses of $\mathrm{Si}$ by seed coating on the physical, physiological and sanitary quality of seeds, as well as to determine the concentration of silicon and calcium absorbed in bean seedlings.

\section{Material and Methods}

The work was carried out in the Didactic Laboratory of Seed Analysis, Seed Pathology and in a greenhouse belonging to the Graduate Program in Seed Science and Technology, at the Eliseu Maciel College of Agronomy, Pelotas Federal University, Capão do Leão - RS.

BRS Expedito beans, 2014/15 harvest, were used, with an initial germination of $82 \%$. It was used as a source of $\mathrm{Si}$, calcium and magnesium silicate powder (Agrosilício ${ }^{\circledR}$ ) (Si: 10.53\%; Ca: 25.00\%; Mg: 7.00\%; Fe: 10.20\%; Cr: 4 , 48\%; Mn: 1.72\%; Ti: 0.69\%; S: 0.52\%; K: 0.35\%), previously sieved, with a density of $1.30 \mathrm{~g} / \mathrm{cm}^{3}$. The treatment consisted of covering bean seeds, in the equivalent doses of $0,45,90,135$ and $180 \mathrm{~g}$ Si $100 \mathrm{~kg}^{-1}$ of seeds, which corresponded to 0 ; $427.3 ; 854.7 ; 1,282 ; 1.709 \mathrm{~g}$ of the product for $100 \mathrm{~kg}^{-1}$ of seeds. The seed coating process was performed manually, using polyethylene bags according to the methodology described by Nunes (2005), in four replications for each dose. The application was made by placing the amount of $\mathrm{Si}$ inside the bag, plus $300 \mathrm{~mL}$ Collor Seed ${ }^{\circledR}$ polymer (red color) and $700 \mathrm{~mL}$ water, to complete the syrup volume from $1 \mathrm{~L}$ to $100 \mathrm{~kg}$ of seed. Afterwards, the products were homogenized at the bottom of the plastic bag, spreading to a height of approximately $15 \mathrm{~cm}$, then placed $0.2 \mathrm{~kg}$ of seeds into the bags, shaking them until a uniform distribution of the product and covering the seeds. After the application of the treatment, the bags with the coated seeds were opened, allowing drying at room temperature for 48 hours (h), followed by physical, physiological, and sanitary tests of the seeds, as well as the concentration of Si. in seedlings as described below:

The weight of one thousand seeds (PMS) 
was determined using four repetitions with eight subsamples of 100 seeds, from the pure seed portion and the results expressed in grams, according to the Rules for Seed Analysis - RAS (BRASIL, 2009). The water content (TA) was determined by the oven drying method at $105 \pm 3$ ㅇ C for $24 \mathrm{~h}$. A forced air circulation oven was used, using four repetitions of five grams of seeds per treatment, according to the RAS (BRASIL, 2009).

For the germination test (G) four repetitions of 200 seeds were used, divided into four subsamples of 50 seeds, using germitest $^{\circledR}$ paper substrate, moistened with distilled water, at a ratio of 2.5 times the dry paper mass and kept in germinator. set at $25 \pm 2^{\circ} \mathrm{C}$. The evaluation of the normal seedling count was performed at nine days after the test installation and the results expressed in percentage, according to the RAS (BRASIL, 2009).

The first germination count (PCG) was performed together with the germination test, constituting the record of the percentage of normal seedlings verified on the nine day after sowing, according to the RAS (BRASIL, 2009) and the results expressed in percentage of normal seedlings.

The cold test (TF) was conducted with four repetitions of 200 seeds divided into four subsamples of 50 seeds, evenly distributed on a germitest ${ }^{\circledR}$ paper roll, previously moistened with distilled water at 2.5 times the weight of dry paper mass. Then the rolls were placed in sealed plastic bags and stored in a refrigerator regulated at $10 \circ \mathrm{C}$ for three days, according to the methodology described by Guiscem et al. (2010). After this period, the rolls were placed in a regulated germinator at a temperature of $25 \pm$ $2^{\circ} \mathrm{C}$, and on the fifth day normal seedling counts were performed.

Accelerated aging (EA) was conducted in gerbox ${ }^{\circledR}$ boxes with aluminum mesh suspended inside the box, where the seeds of each treatment were evenly distributed in four replications. Added $40 \mathrm{~mL}$ of distilled water was added to the bottom of each box, then the boxes were capped and packed inside a BOD type camera, with a controlled temperature of $43 \pm 1^{\circ} \mathrm{C}$ and remaining for a $24 \mathrm{~h}$ period (BERTOLIN et al., 2011). After this period, the seeds were placed to germinate as described in the germination test, the evaluation was performed at five days and the results expressed as percentage of normal seedlings.
For the determination of total seedling length (CTP), root length (CR) and shoot length (CPA), the tests were conducted similarly to the germination test, evaluated on the nine day after sowing, in 10 normal seedlings of the plants. repetitions of each treatment (NAKAGAWA, 1999). The CTP, CR and CPA were determined with the aid of a millimeter graduated ruler and the results expressed in centimeters per seedling.

The total seedling dry mass (MTP), root dry mass (MSR) and shoot dry mass (MSPA) were measured after the length test, the shoot was separated from the root, placed in paper bags and taken to dry in a forced air ventilated oven set at $70^{\circ} \mathrm{C}$ for $72 \mathrm{~h}$. Subsequently, a $0.001 \mathrm{~g}$ scale was used and the results expressed in grams per seedling (NAKAGAWA, 1999). Seedling

emergence (EP) was performed with four replicates of 50 seeds for each treatment, sown in plastic trays containing soil and vermiculite, in a 2:1 $(\mathrm{v} / \mathrm{v})$ ratio. The seeds were sown at a depth of $2.0 \mathrm{~cm}$ and kept in a greenhouse without temperature control, with manual irrigation, close to field capacity, whenever necessary. The evaluation was performed at 21 DAS, computing, as percentages, the number of normal seedlings emerged (NAKAGAWA, 1999).

The emergence speed index (LVI) was conducted in conjunction with the seedling emergence test, through daily emerged seedling counts until emergence stabilization. Root

length (CR21d) and seedling shoot length at 21 days (CPA21d) were determined at the end of the emergency test, where 20 normal seedlings from each repetition were randomly chosen and measured using a millimeter-sized ruler, the results being expressed in centimeters per seedling.

Root dry mass (MSR21d) and shoot dry mass at 21 days (MSPA21d) were determined after seedling length measurement at 21 days, the selected seedlings were separated into root and shoot (leaf and hypocotyl) and arranged. to dry in a forced air circulation oven set at $70^{\circ} \mathrm{C}$ for $72 \mathrm{~h}$. After this period, the samples were weighed on a precision analytical balance and the results expressed in grams per seedling.

To determine the amount of $\mathrm{Si}$ concentration in root, hypocotyl and leaf, samples were taken after the end of the emergency test, where the remaining seedlings of each repetition and treatment were removed from the soil, washed in running water and immediately separated in root, hypocotyl and leaf, which were placed in paper bags and dried 
at $70^{\circ} \mathrm{C}$ for $72 \mathrm{~h}$. Subsequently, they were ground in a Wilcon Marconi ${ }^{\circledR}$ type electric mill with 40 mesh sieves. The Si concentration in the tissues was determined by colorimetric analysis in $0.1 \mathrm{~g}$ of dry tissue, after basic digestion, as determined by Korndörfer et al. (2004).

The sanitary quality evaluation of the seeds was performed by the "Blotter Test" method (filter paper), using 200 seeds for each treatment, divided into four subsamples of 50 seeds, placed in gerbox-type plastic boxes previously disinfected with alcohol. $70 \%$ and $1 \%$ sodium hypochlorite, containing two sheets of sterile filter paper moistened with sterile distilled water. The seeds were incubated at $25 \circ \mathrm{C}$, with $12 \mathrm{~h}$ photoperiod, for $24 \mathrm{~h}$. Then, to inhibit germination the seeds were subjected to the freezing method for $24 \mathrm{~h}$. After this period, they were then incubated again at $25^{\circ} \mathrm{C}$ for seven days with $12 \mathrm{~h}$ light / dark regime (BRASIL, 2009).

The experimental design was completely randomized with four replications. For statistical analysis, the data were subjected to the tests of normality of residues by Shapiro-Wilk and homogeneity of variances by Bartlett, and when they met the assumptions, they were subjected to analysis of variance (ANOVA) and, having data significance, the equations of polynomial regression. The variables that did not meet the assumptions were transformed using the Box-Cox system, making it possible to adjust the data for the ANOVA. For some variables of the seed health test (non-parametric data) the KruskalWallis test was used. For statistical analysis, the SAS software (SAS Institute, 1989, Cary, NC) was used.

\section{Results and Discussion}

Table 1 shows the concentration of nutrients in bean seedlings in seeds covered with different doses of calcium and magnesium silicate. While in table 2 , the results obtained with their regression equations for the physical and physiological variables of seed quality are found.

Table 1. Concentration of silicon and calcium in root, hypocotyl and bean seedlings from seeds coated with calcium and magnesium silicate.

\begin{tabular}{|c|c|c|c|c|c|c|c|c|c|c|}
\hline \multirow{2}{*}{ Evaluation } & \multicolumn{5}{|c|}{ Dose de Si (g 100 $\mathrm{kg}^{-1}$ de seeds) } & \multirow{2}{*}{$\begin{array}{l}\text { CV } \\
\text { (\%) }\end{array}$} & \multirow{2}{*}{$\begin{array}{l}\text { Ideal } \\
\text { dose }\end{array}$} & \multirow{2}{*}{$\mathbf{R}^{2}$} & \multirow{2}{*}{$Y_{E}$} & \multirow{2}{*}{$\begin{array}{c}\text { Regression } \\
\text { equation }\end{array}$} \\
\hline & 0 & 45 & 90 & 135 & 180 & & & & & \\
\hline \multicolumn{11}{|c|}{ Silicon concentration $\left(\mathrm{g} \mathrm{kg}^{-1}\right)$} \\
\hline Root & 8.63 & 9.44 & 9.25 & 8.70 & 8.00 & - & - & - & - & - \\
\hline Hypocotyl & 2.29 & 1.78 & 2.48 & 2.33 & 1.93 & - & - & - & - & - \\
\hline Leaf & 3.14 & 2.81 & 3.75 & 3.65 & 2.98 & 15.3 & 99 & 0.34 & 3.52 & $\begin{array}{c}y=2.92221+ \\
0.01211 x- \\
0.006093 x^{2}\end{array}$ \\
\hline \multicolumn{11}{|c|}{ Calcium concentration $\left(\mathrm{g} \mathrm{kg}^{-1}\right)$} \\
\hline Root & 0.98 & 1.16 & 1.14 & 1.19 & 1.03 & 8.9 & 96 & 0.88 & 1.19 & $\begin{array}{c}y=0.98839+ \\
0.00414 x- \\
0.0002157 x^{2}\end{array}$ \\
\hline Hypocotyl & 1.96 & 1.99 & 2.11 & 1.90 & 2.19 & - & - & - & - & - \\
\hline Leaf & 2.75 & 2.46 & 2.35 & 2.15 & 2.59 & - & - & - & - & - \\
\hline
\end{tabular}

Water content (TA) and weight of one thousand seeds (PMS) were not influenced by Si application at different doses (Table 2). Although there is no significant difference for the PMS, the seed coating promoted increases that ranged from $3.67(1.48 \%)$ to $5.83 \mathrm{~g}(2.33 \%)$ in relation to the zero dose (seeds without covering), this is probably due to the type of texture of Agrosilício $^{\circledR}$, which results in the formation of a structure with granules around the heavier seed (Table 2). Regarding the water content in the seeds, the materials used for polymer, water and Agrosilicon ${ }^{\circledR}$ composite coating did not absorb water, thus demonstrating that time and room temperature were efficient for drying, which can provide safe storage of seeds (XAVIER et al., 2015).

The percentage of normal seedlings in the vigor and germination tests, verified by the variables of first germination count (PCG), germination (G) and cold test (TF), adjusted to a negative linear model (Table 2). As $\mathrm{Si}$ doses increased, there was a reduction rate of approximately 7 percentage points for PCG and 4 percentage points for $G$ and TF at each dose applied via seed treatment. Similar results to 
delayed germination in covered seeds have also been observed by several authors (MEDEIROS et al., 2006; OLIVEIRA et al., 2009; PEREIRA et al., 2005; SILVA et al., 2002; SANTOS et al., 2010). Avelar et al. (2011), when studying the response of covered soybean seeds, concluded that the difference in germination between the tests is not attributed to the decrease in vigor, but to the impediment of germination by the coating.

Table 2. Regression of silicon doses for the variables of physical and physiological quality of seeds.

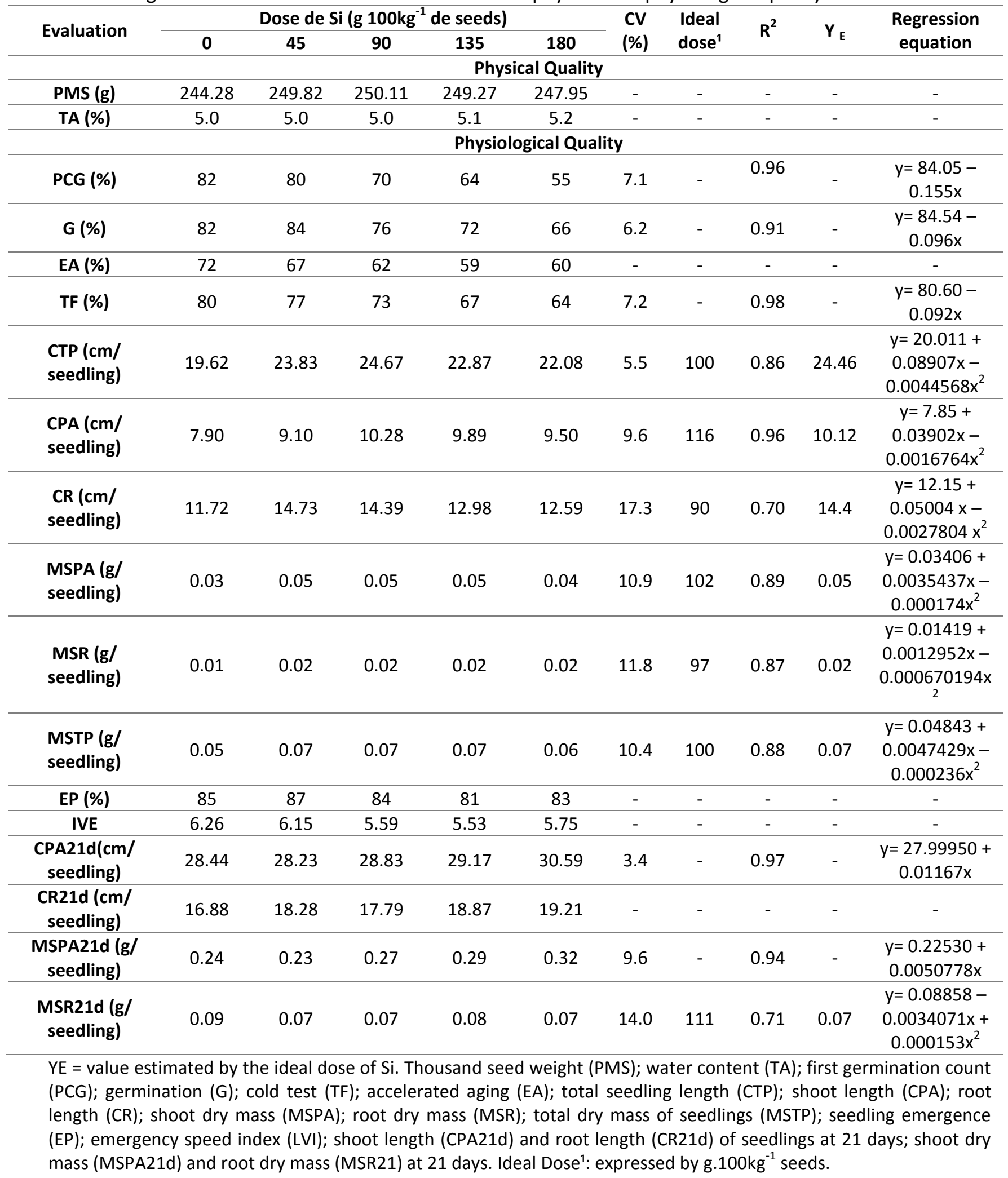


Two possible causes may have influenced the results, one of which is that during seed coating, the formation of a physical barrier imposed by the materials used, which provide protection to the seeds, improving the morphological characteristics. However, delayed germination may occur due to low gas exchange between seeds and the external environment to cover, affecting the oxygen supply necessary for germination and hindering the emission of the primary root. In the absence of oxygen, there is an increase in the production of ethanol in cells, a toxic product for normal metabolism, which enhances seedling malformation (MARCOS FILHO, 2015; XAVIER et al., 2015).

Regarding the accelerated aging (AE), seedling emergence $(\mathrm{PE})$ and emergence speed index (LVI) variables, no significant differences were observed for the Si doses studied (Table 2). In this way, the Si doses did not interfere in the viability of the seeds or in the establishment of the bean seedling stand. However, it is noteworthy that the behavior of the covered seeds did not follow the same pattern as the tests carried out in a germination chamber, compared to those of the greenhouse, since the seeds managed to overcome the physical barrier imposed by the covering during the seedling emergence (Table 2).

Obtaining vigorous seedlings is of fundamental importance because the vigor level affects the establishment of the crop, the development of the plants, the uniformity of the crop and consequently its productivity (MONDO et al., 2016). The data of total seedling length (CTP), shoot length (CPA) and root length (CR) fit into a positive quadratic model, showing that the Si source of Agrosilicon ${ }^{\circledR}$ influenced positively the vigor expression through bean seedling growth, since the optimal dose was reached with 100, 116 and $90 \mathrm{~g} . \mathrm{Si} / 100 . \mathrm{kg}^{-1}$ of seeds, which generated an expectation of 20,22 and $19 \%$ more increment respectively. relation to zero dose (Table 2 ).

It was also observed that the highest shoot dry mass (MSPA), root (MSR) and total seedling dry mass (MSTP) production are associated with the respective length variables, and the data adjusted for a positive quadratic equation. In the optimal Si doses of 102, 97 and $100 \mathrm{~g}$, an expectation of dry matter increases of 37, 30 and $36 \%$ for MSPA, MSR and MSTP, respectively, compared to zero (Table 2). These results corroborate with other studies, which demonstrate that $\mathrm{Si}$ is a beneficial element and that it positively influences the growth rate and the development of seedlings in the initial stages, when provided via covering (CORLETT et al., 2014; RUFINO et al., 2017; TAVARES et al., 2012). Regarding the physiological characteristics of seedling performance evaluated in a greenhouse, there was a linear increase in shoot length at 21 DAS (CPA21d), representing a $7 \%$ increase in the highest dose, compared to zero. However, for root length at 21 days (CR21d), no significant differences were observed between the different doses of Si (Table 1 end table 2). Positive results were also found by Souza et al. (2015) in corn, as the application of calcium and magnesium silicate via soil, with higher emergence rate and initial seedling growth.

As the doses of $\mathrm{Si}$ in the seeds increased, there was a linear increase in the production of dry leaf mass (MSF21d), hypocotyl (MSH21d) and total aerial part (MSPA21d) at 21 days after sowing, representing respectively a dry matter accumulation in 29,25 and $25.4 \%$ at the highest dose compared to the zero dose (Table 2). Although the function of $\mathrm{Si}$ in plant metabolism is not well known, the element has an important role in the synthesis of defense molecules in plants against biotic and abiotic agents, which are observed to have the greatest responses when found in such conditions, however, indirectly the element stimulates plant growth and production, increasing the chlorophyll content in leaf tissues, the photosynthetic rate, changing the architecture of plants and increasing the structural rigidity of tissues (BARBOSA et al., 2015; GUERRA et al., 2014; LOCARNO et al., 2011).

Regarding the root dry mass (MSR21) at 21 days after sowing, the increase of the doses negatively affected the dry matter production, being the data adjusted to the negative quadratic model, with its minimum point at the dose of 111 g. Si/ $100 . \mathrm{kg}^{-1}$ of seeds (Table 1 ). Similar results were observed by Faria Júnior et al. (2009), in rice cultivars submitted to different doses of $\mathrm{Si}$ (calcium silicate) applied via soil, which attributed the fact that it could be related to the cultivation environment, because the plants were conducted in pots, not providing ideal conditions. For a better development of the root system and greater soil exploitation, which consequently reflected in the decrease of dry matter 
production, probably because it caused toxicity in the roots, reducing the transpiration of the plants and the size of the root system.

Regarding the sanitary analysis of the bean seeds coated with Agrosilício $^{\circledR}$, it was observed that independent of the doses of $\mathrm{Si}$, the main microorganisms detected in the seeds were Fusarium sp., Bacteria, Alternaria sp., Penicillium sp., Aspergillus flavus, Cladosporium sp., Collethochum lindemuthianum, Ryzoctonia sp. and Ryzopus sp. (Figure 1 and table 2). According to Braga et al. (2003), the pathogens associated with bean seeds are always the same in Brazil and that they can cause serious damage to seeds. Marcenaro and Valkonen (2016), identified 87 isolates of fungi among them, considered pathogenic Fusarium spp., Collethochum spp., Penicillium sp. and Aspergillus flavus, which caused deterioration of the seeds, rotting of the roots and stems, wilting, necrosis and death of the seedlings.

The figure 1 shows a negative quadratic behavior for the incidence Fusarium sp. in seeds coated with different doses of $\mathrm{Si}$, with the minimum response point observed at the dose of $169 \mathrm{~g}$. Si $/ 100 . \mathrm{kg}^{-1}$ of seeds, corresponding to a reduction of $46 \%$ in relation to zero dose. Inverse result was observed for the incidence of bacteria with increasing doses, with its maximum point at the dose of $152 \mathrm{~g}$. $\mathrm{Si} / 100 . \mathrm{kg}^{-1}$ of seeds.

Figure 1. Incidence of pathogens in bean seeds coated with calcium and magnesium silicate.

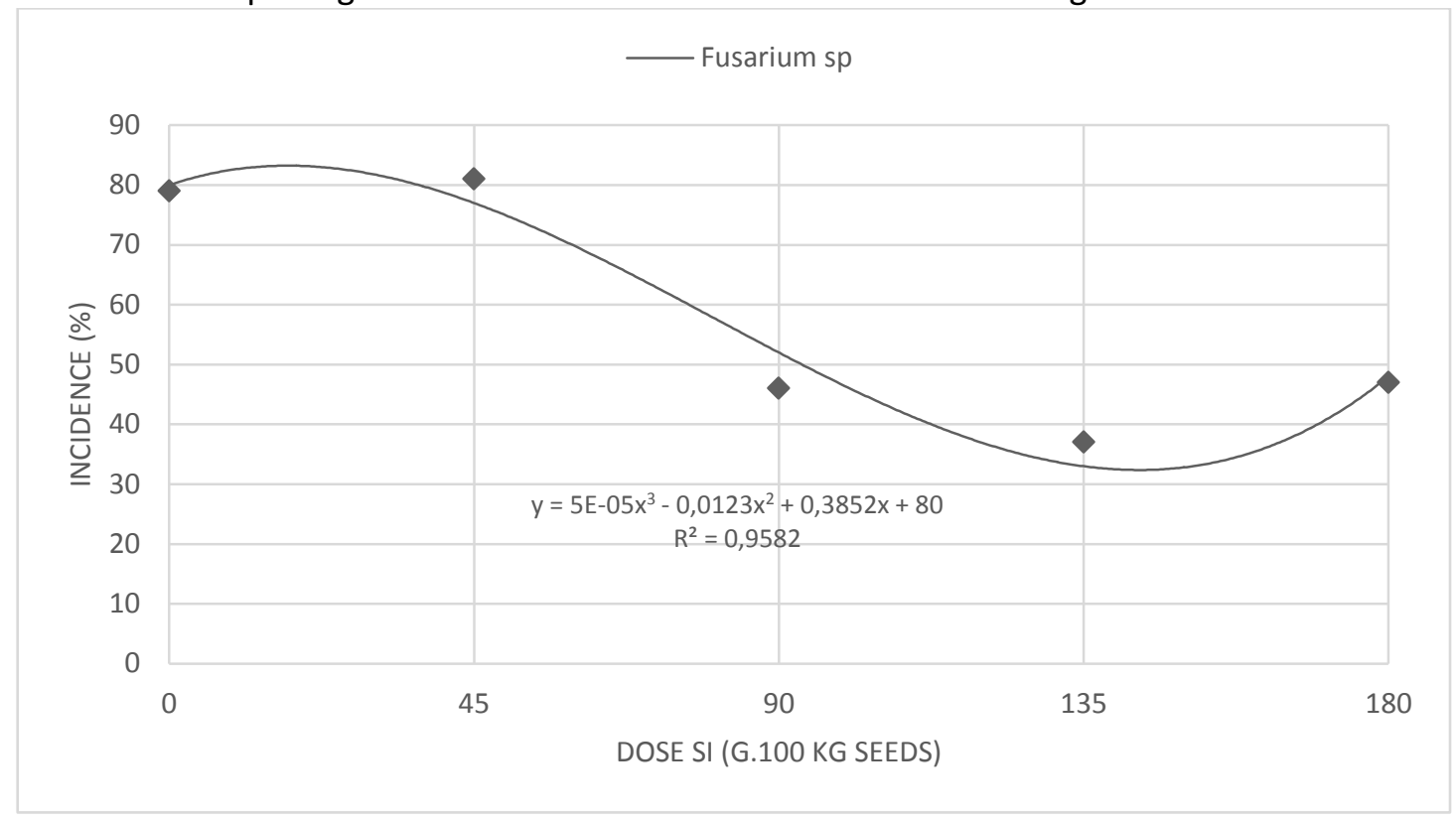

For Penicillium sp., Cladosporium sp., Ryzopus sp., Collethochum lindemuthianum and Ryzoctonia sp. (Table 3), no significant differences between the doses were observed. For Aspergillus flavus and Alternaria sp., there was a reduction of 100 and $99 \%$ in the doses of 135 and 90 g. Si/100. $\mathrm{kg}^{-1}$ of seeds respectively, compared to zero dose, however they did not differ statistically from the other doses. These results demonstrate that the Agrosilício ${ }^{\circledR}$ used for seed coating was not efficient to eradicate the pathogens, except for Aspergillus flavus, and the fungi occurred sporadically in the doses. Seed cover may interfere as a physical barrier, but not as an effective control in eliminating pathogens when associated with seeds. 
Table 3. Incidence of pathogens in bean seeds coated with calcium and magnesium silicate.

\begin{tabular}{lccllll}
\hline \multirow{2}{*}{\multicolumn{1}{c}{ Incidence (\%) }} & \multicolumn{7}{c}{ Dose Si (g 100kg $\mathrm{kg}^{-1}$ seeds) } & \multirow{2}{*}{ Average } \\
\cline { 2 - 6 } & $\mathbf{0}$ & $\mathbf{4 5}$ & $\mathbf{9 0}$ & $\mathbf{1 3 5}$ & $\mathbf{1 8 0}$ & \\
\hline Alternaria sp. & $19.00 \mathrm{a}^{*}$ & $10.50 \mathrm{ab}$ & $1.00 \mathrm{~b}$ & $3.50 \mathrm{ab}$ & $5.50 \mathrm{ab}$ & 7.90 \\
Colletotrichum sp. & $0.50^{\text {ns }}$ & 0.50 & 0.00 & 0.00 & 0.00 & 0.20 \\
Ryzoctonia sp. & 0.00 & 0.00 & 0.50 & 0.00 & 0.50 & 0.20 \\
Penicillium sp. & $9.50^{\text {ns }}$ & 5.00 & 4.00 & 5.50 & 9.00 & 6.60 \\
Aspergillus sp. & $20.50 \mathrm{a}^{*}$ & $1.00 \mathrm{ab}$ & $1.00 \mathrm{ab}$ & $0.00 \mathrm{~b}$ & $2.00 \mathrm{ab}$ & 4.80 \\
\hline
\end{tabular}

* Means followed by the same letter on the line do not differ ( $P>0.01$ ) according to the Kruskal-Wallis test. ns: not significant.

Although increasing doses of $\mathrm{Si}$ through Agrosilício $^{\circledR}$ via seed coating, impaired physiological quality in some laboratory tests (PCG, G and TF), did not compromise the final emergence of seedlings, this is probably due to higher density. In addition, the tests related to seedling growth and development, leaf (Si) and root (Ca) nutrient content were positively influenced by the increase in doses, and it was possible to find satisfactory responses in doses considered ideal among 90 up to $116 \mathrm{~g}$. Si $/ 100 . \mathrm{kg}^{-}$ ${ }^{1}$ of seeds.

\section{Conclusions}

Seed coating with $\mathrm{Si}$ decreases the incidence and severity of Colletotrichum lindemuthianum and provides greater growth of seedlings of bean.

Regarding the physiological characteristics, there was a linear increase in shoot length at 21 DAS (CPA21d), representing a $7 \%$ increase in the highest dose, compared to zero dose. For the physical quality of the bean seeds, the coating process did not change the qualty of the beans.

\section{References}

AVELAR, S. A. G.; BAUDET, L.; PESKE, S. T.; LUDWIG, M. P.; RIGO, G. A. CRIZEL, R. L; OLIVEIRA, S. Armazenamento de sementes de soja tratadas com fungicida, inseticida e micronutriente e recobertas com polímeros líquido e em pó. Ciência Rural, v. 41, n. 10, p. 1719-1725, 2011. https://doi.org/10.1590/S0103$\underline{84782011005000130}$

BARBOSA, M. A. M.; SILVA, M. H. L.; VIANA, G. D. M.; FERREIRA, T. R.; CARVALHO SOUZA, C. L. F.; LOBATO, E. M. S. G.; SILVA LOBATO, A. K. Beneficial repercussion of silicon (Si) application on photosynthetic pigments in maize plants. Australian Journal of Crop Science, v. 9, n. 11 p. 1113-1118, 2015.
BRAGA, N. A.; GOMES PESSOA, M. N.; TEÓFILO, E. $M$. Tratamento químico e biológico de sementes de caupi, Vigna unguiculata (L.) Walp., visando o controle de Macrophomina phaseolina (Tass.) Goid. Revista Ciência Agronômica, v. 34, n. 2, p. 193-199, 2003.

BRASIL. Ministério da Agricultura, Pecuária e Abastecimento. Regras para análise de sementes. Brasília,DF: Mapa/ACS, 2009. 399 p.

BERTOLIN, D. C.; SÁ, M. E.; MOREIRA, E. R. Parâmetros do teste de envelhecimento acelerado para determinação do vigor de sementes de feijão. Revista Brasileira de Sementes, v. 33, n. 1, p. 104-112, 2011. https://doi.org/10.1590/S0101$\underline{31222011000100012}$

CASTELLANOS, C. I. S.; ROSA, M. P .; DEUNER, C .; BOHN, A .; BARROS, A. C. S. A.; MENEGHELLO, G. E. Application of rice husk ash as a silicon source to the soil: effect on the quality of wheat seeds produced under salt stress. Revista de Ciências Agrárias, v. 39, n. 1, p. 95-104, 2016.

https://dx.doi.org/10.19084/RCA15011

CORLETT, F. M. F.; RUFINO, C. A.; VIEIRA, J. F.; TAVARES, L. C.; TUNES, L. V. M.; BARROS, A. C. S. $A$. The influence of seed coating on the vigor and early seedling growth of barley. Ciencia Investigación Agraria, v. 41, n. 1, p. 29-136, 2014. https://doi.org/10.4067/S0718-

$\underline{16202014000100013}$

DEBONA, D.; RODRIGUES, F. A.; DATNOFF, L. E.; Silicon's role in abiotic and biotic plant stresses. Annual Review of Phytopathology, v. 55, p. 85107, 2017. https://doi.org/10.1146/annurevphyto-080516-035312 
DEUS, A. C. F.; BÜLL, L. T. Eficiência de escórias de siderurgia na cultura do feijoeiro em sistema de semeadura direta. Ciência Rural, v. 43, n. 10, p. 1783-1789, 2013. https://doi.org/10.1590/S0103$\underline{84782013005000120}$

FARIA JUNIOR, L. A.; CARVALHO, J. G.; PINHO, P. J.; BASTOS, A. R. R.; FERREIRA, E. V. Produção de matéria seca, teor e acúmulo de silício em cultivares de arroz sob doses de silício. Ciência e Agrotecnologia, v. 33, n. 4, p. 1034-1040, 2009. https://doi.org/10.1590/S1413$\underline{70542009000400013 .}$.

GUERRA, A. M. N. M.; RODRIGUES, F. Á.; LIMA, T. C.; BERGER, P. G.; BARROS, A. F.; SILVA, Y. C. R. Capacidade fotossintética de plantas de algodoeiro infectadas por ramulose e supridas com silício. Bragantia, v. 73, n. 1, p. 50-64, 2014. http://dx.doi.org/10.1590/brag.2014.010

GUISCEM, J. M.; FARIAS, A. S.; FIGUEIREDO, R. T.; CHAVES, A. M. S.; FIGUEIREDO, B. T.; PEREIRA, C. F.; ARÁUJO, J. R. G.; MARTINS, M. R. Teste de frio e envelhecimento acelerado na avaliação de vigor de sementes de feijão-frade. Revista de Ciências Agrárias, v. 33, n. 2, p. 182-191, 2010.

HAYNES, R. J. Chapter Three - Significance and Role of $\mathrm{Si}$ in Crop Production. Advances in Agronomy, v. 146, p. 83-166, 2017.

https://doi.org/10.1016/bs.agron.2017.06.001

LOCARNO, M.; FOCHI, C. G.; PAIVA, P. D. O. Influência da adubação silicatada no teor de clorofila em folhas de roseira. Ciência e Agrotecnologia, v. 35, n. 2, p. 287-290, 2011. https://doi.org/10.1590/S141370542011000200008

MARCOS-FILHO, J. Fisiologia de sementes de plantas cultivadas. 2. ed. Londrina: ABRATES, 2015. 660 p.

MITANI, N.; MA FENG, J. Uptake system of silicon in different plant species. Journal of Experimental Botany, v. 56, p. 1255-1261, 2005. https://doi.org/10.1093/jxb/eri121

MONDO, V. H. V.; NASCENTE, A. S.; CARDOSO NETO, M. O. Common bean seed vigor affecting crop grain yield. Journal of Seed Science, v. 38, n. 4, p. 365-370, 2016.

https://doi.org/10.1590/2317-1545v38n4166814
NAKAGAWA, J. Testes de vigor baseados no desempenho das plântulas. In: KRZYZANOWSKI, F. C.; VIEIRA, R. D.; FRANÇA NETO, J. B. Vigor de sementes: conceitos e testes. Londrina: ABRATES, 1999. p. 2-21.

NUNES, J. C. Tratamento de semente: qualidade e fatores que podem afetar a sua performance em laboratório. São Paulo: Syngenta Proteção de Cultivos Ltda, 2005. 16 p.

OLIVEIRA, L. A. de. Silício em plantas de feijão e arroz: absorção, transporte, redistribuição e tolerância ao cádmio. 2009. 157 f. Tese (Doutorado em Energia Nuclear na Agricultura e no Ambiente) - Centro de Energia Nuclear na Agricultura, Universidade de São Paulo, Piracicaba, 2009.

RUFINO, C. A.; TAVARES, E. C.; RAMOS, P. M.; VIEIRA, J. F.; ABREU JUNIOR, J. S.; SILVA, F. J. A.; CORREA, M. F.; GIL, J. M. Performance of soybean seedlings ufon nutrient aplication by seed coating. Brazilian Archives of Biology And Technology, v. 60, p. 1-11, 2017.

https://doi.org/10.1590/1678-4324-2017160128

SANTOS, F. C.; OLIVEIRA, J. A.; PINHO, É. V. R. V.; GUIMARÃES, R. M.; VIEIRA, A. R. Tratamento químico, revestimento e armazenamento de sementes de Brachiaria brizantha cv. Marandu. Revista Brasileira de Sementes, v. 32, n. 3, p. 69-78, $2010 . \quad$ https://doi.org/10.1590/S0101$\underline{31222010000300008}$

SILVA, J.B.C.; NASCIMENTO, W.M. Peletização de sementes de hortaliças. In: NASCIMENTO, W.M. (Ed.). Tecnologia de sementes de hortaliças. Brasília: Embrapa Hortaliças, 2002, p. 309-341.

SILVA, G. C.; GOMES, D. P.; KRONKA, A. Z.; MORAES, M. H. Qualidade fisiológica e sanitária de sementes de feijoeiro (Phaseolus vulgaris L.) provenientes do Estado de Goiás. Semina: Ciências Agrárias, v. 29, p. 29-34, 2008. https://doi.org/10.5433/16790359.2008v29n1p29

SOUZA, J. P. F.; MARTINS, G. L. M.; PEREIRA, A. C.; BINOTTI, F. F. D. S.; MARUYAMA, W. I. Efeito de silicato de cálcio e magnésio no crescimento 
inicial de milho transgênico. Revista de Agricultura Neotropical, v. 2, n. 3, p. 13-17, 2015. https://doi.org/10.32404/rean.v2i3.280

TAVARES, L. C.; RUFINO, C. A.; DÖRR, C. S.; BARROS, A. C. S. A.; PESKE, S. T. Performance of lowland rice seeds coated with dolomitic limestone and aluminum silicate. Revista Brasileira de Sementes, v. 34, n. 2, p. 202-211, 2012. https://doi.org/10.1590/S0101-

$\underline{31222012000200003}$

TUNES, L. V. M.; FONSECA, D. A. R.; MENEGHELLO, G. E.; REIS, B. B.; BRASIL, V. D.;

WANG, S.; LIU, P.; CHEN, D.; YIN, L.; LI, H.; DENG, $X$. Silicon enhanced salt tolerance by improving the root water uptake and decreasing the ion toxicity in cucumber. Frontiers in Plant Science, n.6, n.759, p.1-10, 2015. https://doi.org/10.3389/fpls.2015.00759

XAVIER, P. B.; VIEIRA, H. D.; GUIMARÃES, C. P. Physiological potential of stylosanthes cv. Campo Grande seeds coated with different materials. Journal of Seed Science, v. 37, n. 2, p. 117-124, 2015. https://doi.org/10.1590/2317$\underline{1545 v 37 n 2145982}$ 